\title{
Synthesis of nanocrystalline zirconia-based powder for surgery implants and study of radionuclides content in it
}

\author{
A.V.Shevchenko, V.V.Lashneva, V.A.Dubok, E.V.Dudnik, \\ V.V.Tsukrenko, A.K.Ruban, V.V.Trishin", I.A.Malyuk*
}

I.Frantsevich Institute for Problems of Materials Science, National Academy of Sciences of Ukraine, 3 Krzhizhanovsky Str., 03680 Kiev, Ukraine

*Institute for Nuclear Research, National Academy of Sciences of Ukraine, 47 Nauky Ave., $03680 \mathrm{Kiev,} \mathrm{Ukraine}$

Received July 7, 2014

Nanocrystalline powder of $\mathrm{ZrO}_{2}\left(5 \% \mathrm{Y}_{2} \mathrm{O}_{3}, 3 \% \mathrm{CeO}_{2}\right)$ has been synthesized. The powder is developed for manufacture of ceramic implants for bone surgery. Physicochemical properties of the powder and its radioactivity have been examined. It is shown that the proposed technology allows to produce the nanocrystalline $\mathrm{ZrO}_{2}$ based powder of high chemical purity and high activity for sintering. Ceramics made of the powder provides the high reliability and assures long term service in the aggressive environment of a living organism. The specific radioactivity of the powder is $(1.3 \pm 0.4) \mathrm{Bq} / \mathrm{kg}$ and is caused by the presence in the powder of natural radionuclide ${ }^{226} \mathrm{Ra}$. Radioactivity of the synthesized powder is more than 100 times below the norm accepted by the international standards for ceramic materials based on $\mathrm{T}-\mathrm{ZrO}_{2}$ for surgical implants.

Синтезировано нанокристаллический порошок $\mathrm{ZrO}_{2}\left(5 \% \mathrm{Y}_{2} \mathrm{O}_{3}, 3 \% \mathrm{CeO}_{2}\right)$. Порошок предназначен для изготовления керамических имплантатов для костной хирургии. Исследованы физико-химические свойства порошка и его радиоактивность. Показано, что использованная технология позволяет получать нанокристаллический порошок на основе $\mathrm{ZrO}_{2}$ высокой химической чистоты и высокой активности при спекании. Керамика, изготовленная из этого порошка, обеспечивает высокую надежность и многолетний срок службы в агрессивной среде живого организма. Удельная радиоактивность синтезированного порошка равна $(1,3 \pm 0,4)$ Бк/кг и обусловлена присутствием в нем природного радионуклида ${ }^{226} \mathrm{Ra}$. Такая радиоактивность более чем в 100 раз ниже нормы, допустимой международными стандартами для керамических материалов на основе $\mathrm{T}-\mathrm{ZrO}_{2}$ для хирургических имплантатов.

Синтез нанокристалічного порошку на основі діоксиду цирконію для хірургічних імплантатів і дослідження вмісту радіонуклідів у ньому. О.В.Шевченко, В.В.Лашнева, В.А.Дубок, О.В.Дуднік, В.В.Цукренко, О.К.Рубан, В.В.Тришин, І.А.Малюк.

Синтезовано нанокристалічний порошок $\mathrm{ZrO}_{2}\left(5 \% \mathrm{Y}_{2} \mathrm{O}_{3}, 3 \% \mathrm{CeO}_{2}\right)$. Порошок призначений для виготовлення керамічних імплантатів для кісткової хірургії. Досліджено фізико-хімічні властивості порошку та його радіоактивність. Показано, що технологія, яку застосували, дозволяє отримувати нанокристалічний порошок на основі $\mathrm{ZrO}_{2}$ високої хімічної чистоти та високої активності при спіканні. Кераміка з цього порошку забезпечує високу надійність і багаторічний термін експлуатації у агресивному середовищі живого організму. Питома радіоактивність синтезованого порошку становить $(1,3 \pm 0,4)$ Бк/кг i обумовлена наявністю в ньому природнього радіонукліду ${ }^{226} \mathrm{Ra}$. Така радіоактивність більш ніж в 100 разів нижче норми, яка прийнята міжнародними стандартами для керамічних матеріалів на основі $\mathrm{T}-\mathrm{ZrO}_{2}$ для хірургічних імплантатів. 


\section{Introduction}

Ceramics based on zirconium dioxide $\left(\mathrm{ZrO}_{2}\right)$ is a very perspective material for variety medical applications due to superposition of such properties as high biological and chemical inertness, increased strength, hardness, the highest among oxide ceramics fracture toughness, wear and corrosion resistance. Since the end of the last century, this material is widely used in dentistry, orthopedics and traumatology to produce ceramic implants, such as pins, crowns, ceramic heads for joints and other devices that run in aggressive environment of a living organism under significant loads [1].

High strength of the $\mathrm{ZrO}_{2}$ based ceramics are achieved due to martensitic phase transition type of the tetragonal zirconia (T$\left.\mathrm{ZrO}_{2}\right)$ into monoclinic phase $\left(\mathrm{M}-\mathrm{ZrO}_{2}\right)$ [2]. Among various classes of materials based on $\mathrm{ZrO}_{2}$ the highest strength and fracture toughness inheres to zirconia partially stabilized in the tetragonal phase by $2-3 \mathrm{~mol}$. \% yttrium oxide (Y-TZP). These materials have fine grain structure and the highest values of flexural strength ( $\geq 1500 \mathrm{MPa}$ ) $[3,4]$. However, the record strength values are badly reproducible and are often achieved at the expense of other important characteristics, such as fracture toughness, stability and other properties.

To produce ceramic implants the $\mathrm{Y}-\mathrm{TZP}$ ceramics with composition $\mathrm{ZrO}_{2}(3 \mathrm{~mol}$. $\%$ $\mathrm{Y}_{2} \mathrm{O}_{3}$ ) is mainly used which characterized by high mechanical and aesthetic properties. In particular, its flexural strength is 900$1200 \mathrm{MPa}$, compressive strength $2000 \mathrm{MPa}$ and the fracture toughness $K_{1 C}$ - 9-10 MPa.m ${ }^{1 / 2}[5]$.

However, the operational reliability of the implants made of this material is not sufficiently high. This is due to the fact that the highest possible content of metastable tetragonal phase in the ceramics $\mathrm{ZrO}_{2}$ (3 mol. $\% \mathrm{Y}_{2} \mathrm{O}_{3}$ ), on the one hand, determines the high strength characteristics of the material and, on the other hand, due to metastability of $\mathrm{T}-\mathrm{ZrO}_{2}$ this ceramics is prone to low temperature degradation of the mechanical properties ("aging") in humid and corrosive environments, as interaction with the aggressive environment stimulates the phase transformation $\mathrm{T}-\mathrm{ZrO}_{2} \rightarrow \mathrm{M}-\mathrm{ZrO}_{2}$ in the surface layer of the ceramics. This process is accompanied by increase in volume and occurrence of microcracks, which in turn leads to the increased surface roughness, increase of wear, deterioration of the mechanical properties and ultimately to the implant destruction [6,7]. This phenomenon is a common cause of destruction of $\mathrm{ZrO}_{2}$-ceramic femoral head of the hip joint [8].

At Frantsevich Institute for Problems of Material Science NASU to produce ceramic implants the new ceramic material of $\mathrm{ZrO}_{2}-$ $\mathrm{Y}_{2} \mathrm{O}_{3}-\mathrm{CeO}_{2}$ system has been proposed, namely zirconia doped with yttrium oxide $(4.5-5.4 \%)$ and cerium dioxide (2-3\%) (herein after, \% by weight) [9]. Cerium dioxide is non-toxic and biocompatible material. Ceramics based on zirconia stabilized with ceria shows fracture toughness up to $20 \mathrm{MPa} \cdot \mathrm{m}^{1 / 2}$, but it is rarely considered as a ceramic biomaterial [5].

Due to cojoint $\mathrm{ZrO}_{2}$ stabilization with yttria and ceria, the developed material has high strength, optimal microstructure and improved phase stability in the humid environment. Flexural strength of this material is not less than $600 \mathrm{MPa}$, density - above $6.0 \mathrm{~g} / \mathrm{cm}^{3}$, an average grain size - less than $0.4 \mu \mathrm{m}$, the phase composition $-\mathrm{T}-\mathrm{ZrO}_{2}$, content of $\mathrm{M}-\mathrm{ZrO}_{2}$ - not more than $3 \%$. Wear of this ceramics in a mobility knot with the high molecular weight polyethylene "Chirulen", which is currently used almost in all pairs of friction of hip prosthesesis, is comparable to the wear in the friction pairs with alumina ceramics and CoCrMo alloy the main materials for heads of the modern hip prostheses.

Primary raw material to produce the developed ceramics is zirconium oxychloride which is synthesized from minerals zircon $\left(\mathrm{ZrSiO}_{4}\right)$ and baddeleyite $\left(\mathrm{ZrO}_{2}\right)$, reserves of which in Ukraine are ranked third in the world after Australia and South Africa [10]. The main impurities in these minerals are hafnium (a few percent), silica, iron, calcium, titanium, rare earth elements, niobium, tantalum and others. In some deposits impurities of radionuclides such as uranium (1 \%), thorium (0.2), et al. also are present, due to which the zircon and baddeleyite display weak radioactivity [11]. To produce high purity zirconia and zirconium salts the raw material is subjected to complex processes of purification from impurities, as well as the radionuclide, it is still a fear that a part of radionuclides remains in the final product. Furthermore, the stabilizing additives in the $\mathrm{ZrO}_{2}$ ceramics $-\mathrm{Y}_{2} \mathrm{O}_{3}$ and $\mathrm{CeO}_{2}$ can also contain radioactive impurities inherited from ores.

The objects of the present work are synthesis of high-purity nanocrystalline zir- 
conia powder with composition of $92 \%$ $\mathrm{ZrO}_{2}+5 \% \mathrm{Y}_{2} \mathrm{O}_{3}+3 \% \mathrm{CeO}_{2}$ and study of radionuclide content in it.

\section{Materials and methods}

As initial materials we used zirconium (IV) oxychloride 8 water $\left(\mathrm{ZrOCl}_{2} \cdot 8 \mathrm{H}_{2} \mathrm{O}\right)$, TU 6-09-3677-74 "Zirconium oxychloride 8aqueous" made by the State Research and Production Enterprise "Zirconium", Dneprodzerzhinsk, Ukraine ; yttrium ni-

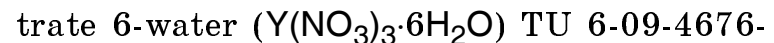
78 "Yttrium nitrate 6-water" powder, LLC "Himstatus", Kharkiv, Ukraine; cerium nitrate 6-aqueous $\left(\mathrm{Ce}\left(\mathrm{NO}_{3}\right)_{3} \cdot 6 \mathrm{H}_{2} \mathrm{O}\right)$, TU 6-094081-84 "Cerium (111) nitrate 6-aqueous (cerium (111) nitrate), pure for analysis " powder PE " Svit", Kharkiv, Ukraine; distilled water GOST 6709-72 "Distilled water. Specifications", IPM NASU; hydrochloric acid $(\mathrm{HCl})$ GOST 3118 "Hydrochloric acid. Specifications, Scientific-Production Enterprise "Alfarus", Kyiv, Ukraine; isopropyl alcohol $\left(\mathrm{CH}_{3} \mathrm{CH}(\mathrm{OH}) \mathrm{CH}_{3}\right)$, Scientific-Production Enterprise "Alfarus", Kyiv, Ukraine. Reagents purity corresponded to the mark "Analytical grade".

The nanocrystalline powder of selected composition have been prepared in two stages. First, by high temperature hydrolysis in acid medium the nanocrystalline powder of $\mathrm{M}-\mathrm{ZrO}_{2}$ was synthesized, and then through mechanochemical and thermal treatments $\mathrm{Y}_{2} \mathrm{O}_{3}$ and $\mathrm{CeO}_{2}$ were implemented in it. Combination in the process of synthesis of stabilized nanocrystalline $\mathrm{T}-\mathrm{ZrO}_{2}$ the benefits of hydrothermal method and mechanochemical processing allows to produce the high-purity, active for sintering powder with complex composition and controlled dispersity $[12,13]$.

For hydrothermal treatment (HTT) in acidic medium the initial aqueous solution of zirconium oxychloride with concentration of $\mathrm{ZrO}_{2} 85 \mathrm{~g} / \mathrm{l}$ was prepared by dissolving the calculated amount of zirconium oxychloride in boiling distilled water at constant stirring until complete dissolution of the salt. The resulting solution was cooled to the room temperature, filtered, and placed into a cooling chamber for settling at temperature of $10{ }^{\circ} \mathrm{C}$ for at least $20 \mathrm{~h}$. After settling, during which a precipitate of undissolved impurities was formed, the solution was separated from the deposit and placed in a laboratory autoclave. Hydrothermal treatment was carried out at temperature of $170{ }^{\circ} \mathrm{C}$ for $6 \mathrm{~h}$. The suspension formed after the HTT was poured into a glass beaker and protractedly asserted until the precipitate formation. The resulting precipitate was separated from the mother liquor, washed repeatedly first with hydrochloric acid $(\mathrm{pH}<2)$ and then with distilled water $(\mathrm{pH} \approx 7)$ and dried at the room temperature in the azeotropic mixture of distilled water with isopropyl alcohol (87.9\% isopropyl alcohol).

For implementation of the stabilizing additives the dry powder of $\mathrm{M}-\mathrm{ZrO}_{2}$ was impregnated with the aqueous solutions of required amounts of yttrium and cerium nitrates. The resulting mixture was comminuted and homogenized for $2 \mathrm{~h}$ in a planetary mill produced by the Design Department of IPMS NASU with cylinder and milling bodies made of zirconia ceramics at frequency of $200-300 \mathrm{rpm}$. Then the mass was transferred into a corundum crucible, placed into electric furnace and calcined for 2 hours in air at $600{ }^{\circ} \mathrm{C}$. To prevent intense discharge of water vapor and nitrogen oxides, which accompanied by loss of the powder particles with them the temperature in the furnace at a ranging from 20 to $200{ }^{\circ} \mathrm{C}$ was increased at a rate not exceeding $1{ }^{\circ} \mathrm{C} / \mathrm{min}$. The further increase up to the final calcination temperature carried out arbitrarily. After isothermal holding the powder was cooled together with the furnace to the room temperature.

Physico-chemical properties of the synthesized powder were studied by wet chemical analysis, atomic emission spectrometry, $\mathrm{X}$-ray diffraction and electron microscopic analyzes. X-ray studies were performed with DRON-1.5 (CuK $\alpha$ radiation, scanning rate $\left.1-4{ }^{\circ} \mathrm{C} / \mathrm{min}\right)$. Size of the primary particle was calculated by the Scherrer formula. Electron microscopic studies were performed with Camebax SX-50. The specific surface area was determined by the method of nitrogen adsorption at the liquid nitrogen temperature (BET).

Radioactivity was investigated by radiometry and high resolution gamma-spectrometry with a gamma-spectrometry complex firm CANBERRA. As a sample for study the synthesized zirconia powder sample was used weighing $100 \mathrm{~g}$.

\section{Results}

According to X-ray and electron microscopic measurements results the powder produced by hydrothermal treatment consists of monoclinic zirconium dioxide with specific surface area $-98.2 \mathrm{~m}^{2} / \mathrm{g}$ and 


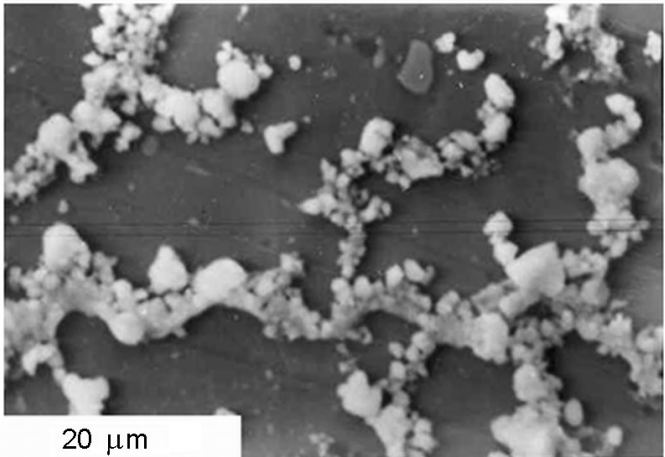

Fig. 1. Structure of $\mathrm{M}-\mathrm{ZrO}_{2}$ nanocrystalline powder obtained by hydrothermal treatment in acidic medium.

pycnometric density $-3.75 \mathrm{~g} / \mathrm{cm}^{3}$. The powder consists of agglomerates with spherical shape, and size from $2.1 \mu \mathrm{m}$ to $7.5 \mu \mathrm{m}$. Average size of the powder primary particles is about $11 \mathrm{~nm}$ (Fig. 1).

After mechanochemical and thermal treatment of the mixture the $\mathrm{M}-\mathrm{ZrO}_{2}$ powder with yttrium and cerium nitrate solutions the zirconia powder doped with oxides of yttrium and cerium was produced. According to the wet chemical and atomic emission spectrometry analyzes the content of main components $\left(\mathrm{ZrO}_{2}, \mathrm{Y}_{2} \mathrm{O}_{3}, \mathrm{CeO}_{2}\right)$ in the synthesized $\mathrm{ZrO}_{2}\left(\mathrm{Y}_{2} \mathrm{O}_{3}, \mathrm{CeO}_{2}\right)$ powder is not less than $99 \%$. The content of $\mathrm{Y}_{2} \mathrm{O}_{3} \approx 5.0 \% ; \mathrm{CeO}_{2} \approx 3.0 \%$. The total content of other impurities $\left(\mathrm{Al}_{2} \mathrm{O}_{3}, \mathrm{SiO}_{2}, \mathrm{CaO}\right.$, $\mathrm{MgO}, \mathrm{Na}_{2} \mathrm{O}, \mathrm{Fe}_{2} \mathrm{O}_{3}$ ) does not exceed $1 \%$. By the phase composition the powder is a mixture of two low-temperature $\mathrm{ZrO}_{2}$ modifications: metastable cubic $\left(\mathrm{F}-\mathrm{ZrO}_{2}\right)$ and tetragonal $\left(\mathrm{T}-\mathrm{ZrO}_{2}\right)$. Pycnometric density of the powder is $5.56 \mathrm{~g} / \mathrm{cm}^{3}$, specific surface $-94.5 \mathrm{~m}^{2} / \mathrm{g}$. The size of the powder agglomerates is $5-10 \mu \mathrm{m}$, with some agglomerates being with the size of $15-20 \mu \mathrm{m}$. The average size of the primary particles is $12 \mathrm{~nm}$. The structure of the powder after mechanochemical treatment and calcination at $600{ }^{\circ} \mathrm{C}$ is shown at Fig. 2 .

Radiometric and gamma-spectrometric studies identified in the synthesized zirconia powder sample the radium-226 $\left({ }^{226} \mathrm{Ra}\right)$ natural radionuclide with a specific activity $(1.30+0.40) \mathrm{Bq} / \mathrm{kg}$. Activity of other radionuclides, in particular, uranium-238 $\left({ }^{238} \mathrm{U}\right)$, and thorium-232 $\left({ }^{232} \mathrm{Th}\right)$ is below sensitivity of the employed apparatus.

\section{Discussion}

The presented data reveal that after hydrothermal treatment of zirconium oxychlo-

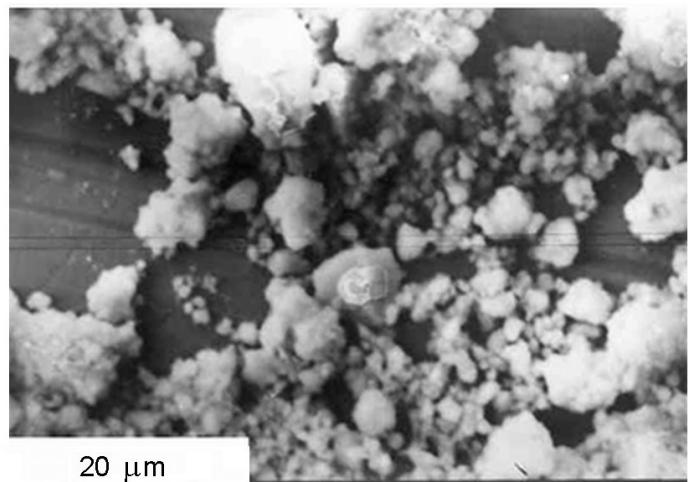

Fig. 2. Structure of the synthesized powder $\mathrm{ZrO}_{2}\left(5 \% \mathrm{Y}_{2} \mathrm{O}_{3}, 3 \% \mathrm{CeO}_{2}\right)$ after heat treatment during $2 \mathrm{~h}$ at $600{ }^{\circ} \mathrm{C}$.

ride solution the nanocrystalline agglomerated powder of monoclinic zirconia $\mathrm{M}-\mathrm{ZrO}_{2}$ was produced. The primary particles and agglomerates in the powder are rounded.

After mechanochemical and thermal treatments of the $\mathrm{M}-\mathrm{ZrO}_{2}$ powder mixture with solution of yttrium and cerium nitrates the rounded form of the primary particles and agglomerates, and sizes of the primary particles in the synthesized powder retained substantially the same as for initial $\mathrm{M}-\mathrm{ZrO}_{2}$ powder after hydrothermal synthesis. However, the agglomerates size increases up to $5-10 \mu \mathrm{m}$ and the separate agglomerates of $15-20 \mu \mathrm{m}$ are observed, specific surface area slightly decreases from $98.2 \mathrm{~m}^{2} / \mathrm{g}$ to $94.5 \mathrm{~m}^{2} / \mathrm{g}$, pycnometric density increases from $3.75 \mathrm{~g} / \mathrm{cm}^{3}$ to $5.56 \mathrm{~g} / \mathrm{cm}^{3}$. Phase composition of the doped powder consists of a mixture of two metastable low-temperature modifications of $\mathrm{ZrO}_{2}$. During the subsequent sintering of ceramic made of the powder the tetragonal zirconia is formed.

Using the hydrothermal treatment of zirconium oxychloride solution it was yielded the monoclinic zirconia powder with "soft" agglomerates which upon further calcination at $600{ }^{\circ} \mathrm{C}$ do not form hard aggregates of the nanocrystalline particles, and it can be easily broken during pressing. The zirconia powder synthesized by this method does not require additional grinding and retains high activity for sintering during prolonged storage.

The results of the chemical and spectral analyzes reveals that the produced powder consists of $\mathrm{ZrO}_{2}\left(5 \% \mathrm{Y}_{2} \mathrm{O}_{3}, 3 \% \mathrm{CeO}_{2}\right)$ and has high chemical purity, with content of the main components $\left(\mathrm{ZrO}_{2}, \mathrm{Y}_{2} \mathrm{O}_{3}, \mathrm{CeO}_{2}\right)$ corresponding to the calculated value. The high purity of the powder was achieved due 
to purification of zirconium oxychloride aqueous solution from the suspended solids by filtration, and then continuously asserted at the low temperature (not above $10{ }^{\circ} \mathrm{C}$ ). During this process the most of insoluble and little soluble impurities went to precipitate, which was separated by decantation. Thus it permitted to reduce in the synthesized powder the content of such impurities as $\mathrm{SiO}_{2}, \mathrm{Cr}_{2} \mathrm{O}_{3}, \mathrm{Al}_{2} \mathrm{O}_{3}, \mathrm{Na}_{2} \mathrm{O}, \mathrm{Fe}_{2} \mathrm{O}_{3}, \mathrm{CaO}$, and others, including radionuclides. Washing of $\mathrm{M}-\mathrm{ZrO}_{2}$ precipitate, produced during hydrolysis, first with hydrochloric acid $(\mathrm{pH}<2)$ and then distilled water $(\mathrm{pH} \approx 7)$ allows to clean the precipitate out of impurities soluble in these liquids $\left(\mathrm{Fe}^{+3}, \mathrm{Al}^{+3}, \mathrm{Cr}^{+3}, \mathrm{Na}^{+}\right.$ etc.). Drying of the precipitate in the azeotropic mixture of distilled water with isopropyl alcohol (87.9 \% isopropyl alcohol) afforded to remove the remaining amount of $\mathrm{H}_{2} \mathrm{O}$. This prevents formation of the hard agglomerates, reduces the interval of agglomerate size distribution, increases monodispersity of $\mathrm{M}-\mathrm{ZrO}_{2}$ powder, and also provides the increase of density of green compacts made of the powder by pressing. Besides mentioned above it takes places decrease of pore sizes in this compact, increase of pore monodispersity and thus improvement of quality and reliability of ceramics made of this powder. Implementation of the stabilizing additives in the high purity nanocrystalline powder of $\mathrm{M}-\mathrm{ZrO}_{2}$ by prolonged grinding in a planetary ball mill provides a uniform distribution of $\mathrm{Y}_{2} \mathrm{O}_{3}$ and $\mathrm{CeO}_{2}$ at nanolevel in all volume of the powder, i.e. uniform chemical and phase composition of the produced $\mathrm{T}-\mathrm{ZrO}_{2}$. It provides also avoiding of the loss of the stabilizing oxides during co-precipitation of yttrium and cerium salts and increasing the chemical purity due to reduced amounts of the impurities, which would fall into the precipitate during precipitation. The formation of the solid solution occurs in the process of grinding and ends in the heat treatment.

Natural radionuclides ${ }^{226} \mathrm{Ra}$ identified in the synthesized zirconia powder by radiometric and gamma-spectrometric methods is the most long-lived among the radium isotopes. Its half-life is about 1600 years [14, 15]. Radium is a chemical element in Group II of the Periodic System, has chemical properties similar to alkaline earth elements and is a chemical analog of barium. ${ }^{226} \mathrm{Ra}$ in humans behaves like Ca. The average content of ${ }^{226} \mathrm{Ra}$ in humans is $0.85 \mathrm{~Bq} / \mathrm{kg} \mathrm{Ca}$ that corre- sponds to a specific activity of $0.17 \mathrm{~Bq} / \mathrm{kg}$ bone muscle $-0.092 \mathrm{~Bq} / \mathrm{kg}$ [16].

The synthesized powder is developed for the manufacture of ceramic implants, in particular the heads of total hip endoprosthesis, which should be implanted into the body to replace broken or destroyed by bone disease hip joint, as well as dental implants (artificial tooth root) which are used as support for installation of the removable and fixed dental prosthesis. Weight of the ceramic head made of $\mathrm{ZrO}_{2}$ ceramics is about $50 \mathrm{~g}$, the dental implant - not more than $1 \mathrm{~g}$.

In accordance with the requirements of international standards for materials using for implants, radioactivity of the $\mathrm{ZrO}_{2}$ based ceramics, defined as the sum of the specific activities of ${ }^{238} \mathrm{U},{ }^{226} \mathrm{Ra}$ and ${ }^{232} \mathrm{Th}$, should not exceed $200 \mathrm{~Bq} / \mathrm{kg}[17,18]$. The specific activity of ${ }^{226} \mathrm{Ra}$ in the synthesized powder is $(1.3 \pm 0.4) \mathrm{Bq} / \mathrm{kg}$, the activities of ${ }^{238} \mathrm{U}$ and ${ }^{232} \mathrm{Th}$ are below the sensitivity of the employed apparatus. Thus, the radioactivity of the synthesized powder is in more than 100 times less than the allowable level. In addition, the ceramic head in the implanted endoprosthesisis partially screened by polyethylene liner with thickness of about $5 \mathrm{~mm}$ and a titanium cup with thickness of about 1.5-2 mm. Besides mentioned above there is screening of inner parts of the ceramic head due to absorption by the outer layers of the head. For these reasons, the acting dose of radiation is reduced by another 2-3 orders of magnitude. Natural radioactivity of the removed for implantation part of the bone is bigger. Thereby implantation of hip endoprosthesis with $\mathrm{ZrO}_{2}$-based ceramic head (made of the ceramics powder described here) in fact does not change the natural background radiation of the body.

\section{Conclusions}

High purity nanocrystalline zirconiabased powder with chemical composition $92 \% \mathrm{ZrO}_{2}+5 \% \mathrm{Y}_{2} \mathrm{O}_{3}+3 \% \mathrm{CeO}_{2}$, synthesized by the described route consists of soft uniform agglomerates with predominant size of 5-10 $\mu \mathrm{m}$, ensures reliability and durability of the ceramics made from it in the aggressive environment of a living organism, preserves increased activity for sintering even after prolonged storage .

Radioactivity of the powder defined as the sum of the specific activities of ${ }^{238} \mathrm{U}$, ${ }^{226} \mathrm{Ra}$ and ${ }^{232} \mathrm{Th}$ in fact consists mainly of ${ }^{226} \mathrm{Ra}$ activity and is in more than 100 times below the norm acceptable by in- 
ternational standards for ceramics based on tetragonal zirconia for the surgical implants.

The synthesized powder can be beneficial for medical applications, in particular to produce the ceramic implants for dental and orthopedic surgery.

Acknowledgement. The work was supported by Program of fundamental researches of National Academy of Sciences of Ukraine "Fundamental Problems of nanostructured systems, nanomaterials and nanotechnologies" (Project $108 \mathrm{H}$ ).

\section{References}

1. A.S.Vlasov, T.A.Karabanova, Glass and Ceramics, 9-10, 25 (1993).

2. A.V.Shevchenko, A.K.Ruban, E.V.Dudnik, $R e-$ fract. and Techn. Ceram., 9, 2 (2000).

3. P.F.Manicone, P.R.Iommetti, L.Raffaelli, $J$. Dentistry, 35, 819 (2007).

4. New Materials, ed. by J.S.Karabasova, MISSIS, Moscow (2002) [in Russian].

5. Zirconium, Zircon, Zirconium Dioxide [Electronic resource] / Access mode: www.URL:// http://www.espadent.ru/index.php/2011-0419-14-18-22.

6. L.Gremillard, J.Chevalier, T.Epicier et al., $J$. Eur.Ceram.Soc., 24, 3483 (2004).

7. J.Chevalier, L.Gremillard, S.Deville, Annu. Rev.Mater.Res., 37, 1 (2007).
8. G.Maccauro, C.Piconi, W.Burger et al., $J$. BoneYoint ( $\mathrm{Br}$ ), 86-B, 1192 (2004).

9. A.V.Shevchenko, V.V.Lashneva, E.V.Dudnik et al., Nanosyst., Nanomater., Nanotechnol. Collect. Sci. Papers, 9, 882 (2011).

10. 1996-2001 year. Zirconium Industry in the World, Russia, Kazakhstan and Ukraine [Electronic Resource] /Access Mode: www.URL://http://www.74rif.ru/Cr-2001.h tml.

11. Zirconium Minerals, Ores and Ore Concentrates [Electronic Resource]/ Access Mode: www. URL: //www.http: //The range of the RF. /publ/stati/mineraly_cirkonija_rudy_i_ rudnye koncentraty/5-1-0-111.

12. E.V.Dudnik, Powder Metallurgy, 3/4, 146 (2009).

13. A.V.Shevchenko, in: Inorganic Materials Science. Foundations of Materials Science, v.2, Naukova Dumka, Kiev, (2008), p.272.

14. I.A.Leenson, Chemistry and Life, 7, 36 (2009).

15. Information about the Chemical Element "Radiy" [Electronic Resource] / Access Mode:www.URL://:http://www.chemport.ru /elinfo.php?el $=88$

16. A.A.Moiseev, V.I.Ivanov. Directory for Dosimetry and Radiation Hygiene, Energoatomizdat, Moscow (1990) [in Russian].

17. International Standard ISO 6872:2008. Dentistry - Ceramic Materials.

18. International Standard ISO 13356:2008. Implants for Surgery - Ceramic Materials based on Yttria-stabilized Tetragonal Zirconia (Y-TZP). 